\title{
A Microanalytical Look at Mutual Regulation in Psy- chotherapeutic Dialogue: Dialogic Discourse Analysis (DDA) in Episodes of Rupture of the Alliance
}

\author{
Claudio Martinez Guzman ${ }^{1 \bowtie}$, Alemka Tomicic ${ }^{1}$, Lorena Medina ${ }^{2}, \&$ Mariane Krause $^{3}$
}

\begin{abstract}
The psychotherapeutic process, like any intimate relationship between two human beings, involves mutual self-regulation processes that support effective communication. In psychotherapy, such regulatory processes are necessary to maintaining a positive working alliance and also contribute to therapeutic change. Episodes in which the alliance is ruptured or these ruptures are resolved constitute key moments during which the aforementioned regulatory processes are manifested. This article outlines a micro-analysis of these rupture episodes, using dialogic discourse analysis (DDA) to depict mutual regulation processes in the psychotherapeutic dialogue. DDA is a microanalytic procedure that makes it possible to identify discursive strategies associated with the processes of the construction, failure, and restoration of the psychotherapeutic dialogue. This analytic tool was applied to 34 rupture episodes identified in long-term psychoanalytic therapy. Following this, an emergent model about the discursive regulatory features in episodes of alliance rupture was developed, distinguishing between the overcoming and repairing processes of the alliance ruptures. The core issue for the resolution of ruptures seems to be the ability to regulate the tension between the participants. In this paper, we discuss the processes of repairing and overcoming of the rupture as two alternatives methods for regulating this tension. It is proposed that strategies that are most similar to repairing are more likely to facilitate the occurrence of psychotherapeutic change. Additionally, the discussion focuses on the value of DDA as a microanalytical methodology that makes it possible to comprehensively account for these processes.
\end{abstract}

Keywords: mutual regulation in psychotherapy, dialogic discourse analysis, ruptures of the therapeutic alliance

A way of approaching the therapeutic dyadic exchange involves, on the one hand, understanding how each participant influences his or her own behavior (self-regulation), and, on the other hand, how each of the participants is affected by the other's behavior (mutual regulation) (Beebe, 2006; Beebe \& Lachman, 2002; Tronick, 1998). From this perspective, all dyads become engaged in this interactive regulation process, which takes place continuously at a verbal as well as at a non-verbal level (Tronick, 1989, 1998). This is a continuous,

\footnotetext{
${ }^{1}$ Faculty of Psychology, Universidad Diego Portales, Chile.

${ }^{2}$ Faculty, Pontificia Universidad católica de Chile, Chile.

${ }^{3}$ Psychology Department, Pontificia Universidad católica de Chile, Chile.

$\triangle$ Correspondence concerning this paper should be addressed to Claudio Martinez Guzman, Faculty of Psychology, Universidad Diego Portales, Chile. E-mail: claudio.martinez@ mail.udp.cl.
}

permanent, and bidirectional process, in which mutual regulation and self-regulation are inextricably associated. Their degree of intertwinement is such that some authors (i.e., Beebe, 2006; Beebe \& Lachmann, 2002; Benecke, Peham, \& BänningerHuber, 2005) point out that the regulatory behaviors of one participant (i.e., linguistic markers, speech rhythm, vocal intonation) can be predicted by observing those of the other participant and vice versa. In psychotherapy, an important characteristic of a positive therapeutic alliance is the participants' ability to predict the communicative behaviors of the other party. This not only allows participants to regulate each other but also to adjust their selfregulation processes to the intersubjective field. Thus, depending on the therapist's response to the patient's regulatory behaviors and his/her reaction to it, the relationship will permanently oscillate from states of de-regulation, involving a lack of coordination or rupture of expectations, to states in which such 
deficiencies are repaired (Martínez, 2011; Safran \& Muran, 2000, 2001, 2006; Tronick, 1989). In their studies of the therapeutic alliance, Safran and Muran $(2000,2001,2006)$ describe this regulation process through the concept of negotiation. For these authors, the therapeutic relationship involves a continuous process of intersubjective negotiation, conscious and unconscious, between the participants' need for autonomy and association. In this process, ruptures reflect an interruption of collaboration and a decrease of the quality of the relationship, which can be observed through the patient's direct confrontation with or affective detachment from the therapist (Eubanks-Carter, Muran, Safran, \& Mitchell, 2008). On the other hand, resolutions are strategies aimed at solving these ruptures through the exploration of the patient's feelings and the clarification of misunderstandings (Muran, 2002; Safran \& Muran, 2000, 2001). Ruptures, for these authors, reveal the patient's maladaptive relational patterns and the therapist's acceptance of playing certain roles or meeting certain expectations (Safran \& Muran, 2001), which can result in a lack of affective attunement in the dyad. However, as the therapist becomes part of the patient's relational matrix (Mitchell, 1988; Ogden, 1994), he/she will attain a better understanding of his/her core organizing principles and conflictive emotional patterns and, thus, establish a relationship that makes it possible to expand and reorganize them (Safran \& Muran, 2000). Therefore, the process of intersubjective negotiation in the therapeutic relationship involves a mutual regulation process that can itself be a mechanism of therapeutic change (Beebe \& Lachmann, 2002; Lachmann, 2001; Safran \& Muran, 2000, 2006; Stern et al., 1998; Tronick, 1989, 2001; Tronick \& Cohn, 1989; Tronick et al., 1998). From this point of view, psychotherapy is conceptualized as an exchange of separate subjectivities in an interwoven process that constructs a shared subjective field, which is responsible for the process and the development of the therapy (Orange, Atwood, \& Stolorow, 1997; Stern, 1985; Stolorow \& Atwood, 1992).

In this research field, a frequent and useful way of studying the psychotherapeutic process is to look at specific moments within the therapy. These moments are special episodes, chosen from a theoretical point of view, and include, for example: episodes of change (Krause et al., 2006; Krause et al., 2007), innovative moments (Gonçalves, Matos, \& Santos, 2009), and, in this case, rupture episodes (Safran \& Muran, 1996, 2000,2006 ). These episodes are regarded as "windows" (Elliott, 1984; Timulak, 2007) that make it possible to understand the connection between the therapeutic exchange and its outcome.

Specifically, episodes of alliance ruptures are moments during the therapy in which patienttherapist communication breaks down and a disagreement emerges. These episodes are windows into the patient's relational patterns, because they are associated with both the conscious and unconscious core organizing principles of the patient and the therapist (Safran \& Muran 2000; Stolorow, 2002). These organizing principles participate in the selfregulation and mutual-regulation process, since they are modes of processing and organizing information and affective experiences that guide and direct an individual's interactions in both the personal and interpersonal world (Blatt, 2008; Brandchaft, Doctors, \& Sorter, 2010).

Working through ruptures of the alliance in psychotherapy can provide insight into the patient's potential for negotiating relatedness in the context of interaction rupture. Part of this activity is to repair the relationship, restoring communication after the rupture (Colli \& Lingiardi, 2009; Safran \& Muran, 2000). This action fortifies the trust between the participants by allowing them to see each other from different perspectives, as holding different viewpoints on reality, and to tolerate the lack of omnipotence resulting from not always having the only truth. Exploring and working through alliance ruptures entails an exploration and affirmation of both the separateness and the potential togetherness of the self and the other (Benjamin, 1995; Blatt, 2008; Safran \& Muran, 2000; Winnicott, 1965). Since this activity is a fundamental aspect of the mutual regulation process in all kinds of relationships, it is essential in the psychotherapy field (Beebe, Knoblauch, Rustin, \& Sorter, 2005).

From the point of view of dialogical self theory (DST; Hermans 1996; Hermans \& HermansKonopka, 2010), human communication involves the negotiation of social objects (opinions, options, points of view, perspectives) between an ego and an alter. This negotiation happens within an outside dialogue between two people or within an inner dialogue between different positions of the self (Hermans, 1996; Markova, 2006). These dialogues convey different positions or perspectives, both conscious and unconscious, and their organization in the self is due to relational patterns formed in early infancy that include the ways in which the positions negotiate. Thus, these subjective positions are present in the psychotherapeutic interactional process and act-in either a harmonic or conflictive way-as the participants' core organizing principles (Bahktin, 1986; Hermans, 1996; Hermans \& Lyddon, 2006; Stolorow, 2002).

This process of negotiation happens moment by moment in the therapeutic dialogue and takes part in the self-regulation (inner dialogue) and mutual regulation processes (outside dialogue). When somebody (in an outside or inner dialogue) imposes an argument that is presented as the only possible and objective perspective, he/she eliminates the chance of incorporating alternative perspectives in the dialogue. This kind of argument is regarded as monologic, a 
unique truth that breaks the dialogical negotiation (Gonçalves \& Guilfoyle, 2006). In contrast, if the argument includes or accepts the possibility of other perspectives or several truths, it is considered dialogical and intersubjective and is thought to support the dialogical negotiation process (Marková, 2006; Martínez, 2011). Verbally, these mono- or dialogic arguments express states of the self (Hermans, 1996) that, from the theoretical perspective of DDA, are considered discursive subjects that could be deployed during the psychotherapeutic dialogue (Larrain \& Medina, 2007; Martínez, 2011; Martínez, Tomicic, \& Medina, 2012).

Thus, discursive subjects are equivalent to positions of the self or voices in Bakhtin's terms (2003). They are points of view expressed in an utterance that may, in fact, contain more than one point of view, valuation, or position, thereby constituting its polyphonic aspect. While they are implicit in the speech, it is possible to make them explicit by means of diverse discursive markers (Larraín \& Medina, 2007; Martínez et al., 2012).

In a previous case study (Martinez et al., 2012) specific discursive markers were detected through a DDA microanalysis of therapeutic change and episodes of alliance rupture. It was found that significant psychotherapeutic episodes (change or rupture) present a discursive marker termed a nuclear utterance. This marker condenses the principal elements that account for the discursive subject being deployed during the rupture or change. For example, the following utterance by the patient: "I make sacrifices so that others can enjoy and live well," is a nuclear utterance of the patient's discursive subject called The Martyr (see Table 2), which condenses elements of her sacrifice for others at the cost of her own wellbeing. Therefore, this utterance has a nuclear character because it allows for identifying and characterizing the discursive position of The Martyr in the patient.

Also, it was found that the ruptures were characterized by the presence of a third external voice in the dialogue, capable of being invoked by the therapist. This voice had the effect of giving a monological objectivity and legitimacy to the therapist's position (Martinez et al., 2012). This discursive strategy is typical of some discursive subjects associated with more monologic positions of the self. For instance, this utterance of the therapist: "This thing that happens to you here also happens to you in other places, you have a behavior style or pattern independent from myself' is a monologic argument, used by the therapist's discursive subject named The Teacher (see Table 3). This discursive subject enters the therapeutic dialogue as a third external voice or monologic argument, which, in this case, refers to an external psychological theory to explain the patient's behavior and the therapeutic experience of the here and now.
Finally, in episodes of alliance rupture, it was observed that dialogic discursive markers contributed to the repair process in the relationship. This was thought to produce the activation and validation of the patient's dialogic subjectivity and, in consequence, to restore the intersubjective field (Martinez et al., 2012). This strategy is also typical of discursive subjects associated with more dialogic positions of the self. For example, the following utterance of the therapist: "what does this make you feel?" is a question asked by the therapist's discursive subject named The Proposer (see Table 3), which opens the dialogue to the other's here and now experience.

\section{Aim and Hypotheses}

In this study, we took episodes of rupture, with repair and without repair, and examined them from a microanalytical point of view (Orlinsky, Helge, \& Willutzki, 2004) using dialogical discourse analysis (DDA). The hypotheses were:

1. Episodes of rupture with and without repair will include nuclear utterances that condense the conflict and account for the discursive subject being deployed during the episode.

2. Episodes of rupture without repair will include more discursive subjects employing monologic arguments and linguistic markers that objectivize the relationship.

3. Episodes of rupture with repair will include more discursive subjects employing dialogic arguments and linguistic markers that restore the dialogic intersubjective field.

To assess these hypotheses, a dialogic discourse analysis (DDA) was performed using confirmatory and exploratory strategies, aiming for a microanalytical examination of mutual regulation mechanisms within episodes of alliance rupture. As a result of these analyses, an emergent comprehensive model of the process of resolution of ruptures in the therapeutic alliance was developed.

\section{Method}

A single case design was used to perform qualitative and quantitative analyses of data taken from a longterm psychotherapy. Experts agree that the depth resulting from the systematic exploration of a therapeutic process and the detailed observation of a phenomenon can only be attained by this type of design (Elliot, 2002; Gallassi \& Gersh, 1993; Hilliard, 1993; Kazdin, 1999; Stephen \& Elliot, 2011). Even though there is consensus about the limitations of these designs for the replication and generalization of results, the intensive and extensive recording of the process, the systematic application of quantitative and qualitative measurements, and the implementation of multiple change measu-rements throughout the process (Elliot, 2002) are strategies that contribute to 
the applicability and consistency (Lincoln, \& Guba, 1985) of the results.

\section{Participants}

The rupture episodes were taken from 60 recorded sessions of a long-term psychoanalytic therapy. The therapy started in October 2005 and ended in March 2009 after 120 sessions (one per week), including breaks for holidays and absences. The patient was a 37-year-old woman and the therapist was a 50-yearold man with 30 years of clinical experience. The patient received psychotherapy due to depressive symptoms and interpersonal conflicts. Her clinical history before the beginning of therapy included a period as a psychiatric in-patient and two suicide attempts. The diagnostic hypothesis, made by psychiatrists from a psychiatric institute at the onset of the treatment, was a borderline personality disorder based on Axis II of the Diagnostic and Statistical Manual of Mental Disorders IV (DMS-IV; American Psychiatric Association, 1994).

The treatment was evaluated by mean of two instruments: an outcome measurement using the Outcome Questionnaire 45.2 (OQ-45.2; Lambert \& Burlingame, 1996), and an evaluation of the process of therapeutic change, in which a trained observer applied the observation-based system of generic change indicators (GCIs) and analyzed both the video and transcripts of each of the sessions (see Krause et al., 2006, 2007). The OQ45.2 subscale of disease symptoms showed a slight improvement in the measurements at the end of the treatment with respect to the beginning of therapy. However, the interpersonal relationship and social role subscales remained unchanged throughout the entire process. On the other hand, from the point of view of GCIsthat is to say, the positive transformations of the patient's representations and meanings-the therapy was successful due to the number of changes identified and their high level throughout the whole process (Martínez, 2011). GCIs constitute a hierarchy of indicators that can be divided into three levels reflecting the phases of the psychotherapeutic change process (Altimir, et al., 2010; Echávarri, et al., 2009). The initial level (Level I) is referred to as an initial consolidation of the structure of the therapeutic relationship; the second level (Level II) is considered an intermediate stage and is referred to as an increase in patient's openness toward new understandings; the third level (Level III) is referred to as a construction and consolidation of the patient's new understandings (see Krause, et al., 2007). As Figure 1 shows, the percentage of Level I changes decreased during the process (phase 1 -phase $3=33 \%$, CI [0.06-0.55], $p<0,05$ ), whereas the percentage of Level III changes increased toward the end of the therapy (phase3-phase $1=54 \%$, IC [0.29-0.71], $p<0.05)$. These significant differences support the notion that this therapy displays a positive evolution from the point of view of GCIs.

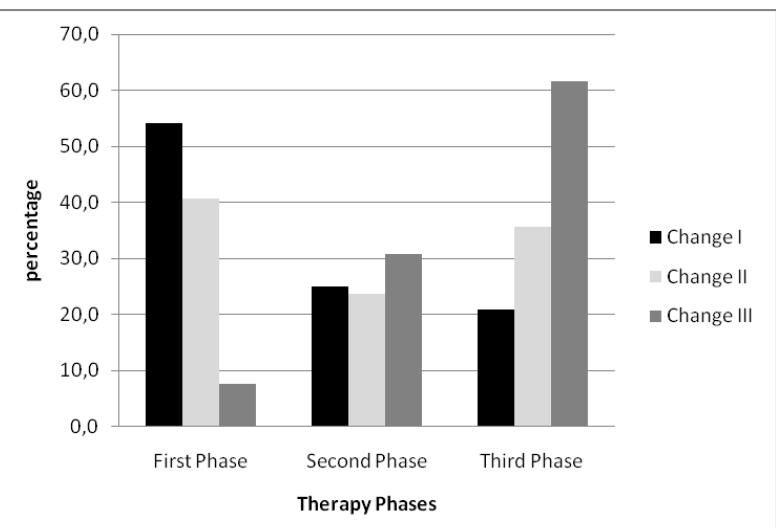

Figure 1. Distribution of Change Episodes in the therapeutic process. First phase corresponds to 10 sessions taken from session 1 to 16; second phase corresponds to 30 sessions taken from session 17 to 58 ; third phase corresponds to 20 sessions taken from 60 to 120 .

Both participants signed informed consents to participate in this study and were aware that the full therapy-one session per week-would be videorecorded.

In this study, the complete collection of episodes of rupture of the therapeutic alliance, taken from the 60 sessions available, was analyzed. This complete collection comprised 34 rupture episodes, 10 of them with repair and the other 24 without repair. As can be seen in Table 1, the episodes were taken from different sessions throughout the therapy.

\section{Procedures}

The identification of the alliance ruptures was carried out using the Rupture Resolution Rating System Manual (Eubanks-Carter, Muran, Safran, \& Mitchell, 2008), which specifies communication markers derived from the two main types of alliance rupture depicted by Safran and Muran (1996, 2000, 2006): withdrawal and confrontation. Sessions recording were coded by trained judges. For the identification of ruptures, an independent evaluation was performed by three independent judges (PhD students). The coding of discursive subjects was performed by the authors of this article. For the analysis of the coding reliability, the kappa index was used; two couples of raters considered the first author of this paper as the reference rater because of his expertise in this kind of coding. The agreement of the three raters was $\operatorname{good}^{1}$, with a

\footnotetext{
${ }^{1}$ The FalliObs software was used to calculate the minimal expected kappa values for these categories (Bakeman, Quera, McArthur, \& Robinson, 1997), and a level of precision of $80 \%$ was defined.
} 
Table 1a. Characterization of the full set of rupture episodes

\begin{tabular}{|c|c|c|c|c|}
\hline \multicolumn{2}{|c|}{ Session/Episode } & Topic & \multirow[t]{2}{*}{$\begin{array}{l}\text { Tipe of } \\
\text { Rupture }\end{array}$} & \multirow{2}{*}{$\begin{array}{c}\begin{array}{c}\text { Kinf of } \\
\text { Resolution }\end{array} \\
\text { With Repair }\end{array}$} \\
\hline 1 & 09 /gen & $\begin{array}{l}\text { The patient misunderstands an interpretation by the } \\
\text { therapist, and thinks he is accusing her of manipulating } \\
\text { the situation to make it seem she is ready to be dis- } \\
\text { charged. }\end{array}$ & & \\
\hline 2 & 12 /gen & $\begin{array}{l}\text { The patient declares that she does not like to be asked } \\
\text { specifics about her life, her feelings. }\end{array}$ & Confrontation & With Repair \\
\hline 3 & 14 /gen & $\begin{array}{l}\text { The patient states that she finds it pointless to keep talk- } \\
\text { ing about her life. }\end{array}$ & Withdrawal & Without Repair \\
\hline 4 & $15 /$ feb & $\begin{array}{l}\text { The patients withdraws into silence, refusing to refer to } \\
\text { something that happened to her. }\end{array}$ & Withdrawal & Without Repair \\
\hline 5 & 17 /gen & $\begin{array}{l}\text { The patient mentions that she does not think therapy } \\
\text { will work for her, that it is impossible for her to change. }\end{array}$ & Confrontation & Without Repair \\
\hline 6 & $17 /$ feb & $\begin{array}{l}\text { "It doesn't matter what I do, you don't care, because I'm } \\
\text { just another patient." }\end{array}$ & Confrontation & With Repair \\
\hline 7 & 23 /gen & $\begin{array}{l}\text { The patient complains that therapy has not resulted in } \\
\text { any changes, and that she is tired of coming and "ending } \\
\text { up more confused." }\end{array}$ & Confrontation & Without Repair \\
\hline 8 & $23 /$ feb & $\begin{array}{l}\text { The patient declares that she does not like others to } \\
\text { meddle in her sex life and does not want this topic dis- } \\
\text { cussed in the therapy. }\end{array}$ & Confrontation & With Repair \\
\hline 9 & 24 /gen & $\begin{array}{l}\text { The patient says she is unsure that the therapy is help- } \\
\text { ing, that she makes an effort to come and can see no re- } \\
\text { sults. }\end{array}$ & Confrontation & With Repair \\
\hline 10 & 25 /gen & $\begin{array}{l}\text { The patient thinks that the treatment is not working, } \\
\text { and asks the therapist how many more sessions she } \\
\text { needs. }\end{array}$ & Confrontation & With Repair \\
\hline 11 & $26 /$ feb & $\begin{array}{l}\text { The patient does not want to collaborate; she refuses to } \\
\text { speak or think during the session. Long silences or mon- } \\
\text { osyllables reveal her discomfort during the session. }\end{array}$ & Withdrawal & Without Repair \\
\hline 12 & $26 / a p r$ & $\begin{array}{l}\text { The patient states she is in a sulk and does not want to } \\
\text { waste her or the therapist's time. }\end{array}$ & Confrontation & Without Repair \\
\hline 13 & $28 /$ feb & $\begin{array}{l}\text { The patient refuses to say what she wants, although she } \\
\text { feels troubled. There is something she prefers to keep to } \\
\text { herself. }\end{array}$ & Withdrawal & With Repair \\
\hline 14 & $29 /$ feb & $\begin{array}{l}\text { The patient states that she does not want to come to the } \\
\text { sessions anymore because she has no hope of changing. }\end{array}$ & Confrontation & With Repair \\
\hline 15 & 33 /gen & $\begin{array}{l}\text { The patient wishes to know details of the therapist's } \\
\text { personal life and the therapist does not answer, or does } \\
\text { so vaguely and indirectly. }\end{array}$ & Confrontation & With Repair \\
\hline 16 & $33 / \mathrm{mar}$ & $\begin{array}{l}\text { The patient is very upset because she thinks that the } \\
\text { therapist is trying to solve problems in a way she thinks } \\
\text { is superficial. }\end{array}$ & Confrontation & Without Repair \\
\hline 17 & 33 /apr & $\begin{array}{l}\text { The patient says that the session left her feeling bad, and } \\
\text { that she is more confused than when she arrived. }\end{array}$ & Confrontation & Without Repair \\
\hline 18 & $33 / \mathrm{mag}$ & $\begin{array}{l}\text { The patient requests to end the session earlier because } \\
\text { she feels uncomfortable in her relationship with the } \\
\text { therapist. }\end{array}$ & Withdrawal & Without Repair \\
\hline 19 & 38 /gen & The patient finds it pointless to discuss her past. & Withdrawal & Without Repair \\
\hline 20 & 45 /gen & $\begin{array}{l}\text { Both participants speak about different things, which } \\
\text { creates confusion. }\end{array}$ & Withdrawal & Without Repair \\
\hline
\end{tabular}

kappa value of $0.69(\mathrm{SE}=0.8, p=0.00)$ for the first couple of independent raters, and $\mathrm{k}=0.75$ ( $\mathrm{SE}=0.78$, $p=0.00$ ) for the second couple of raters. For the temporal delimitation of the rupture episodes and those in which a low degree of agreement was reached, an adjustment process was carried out between the raters through an intersubjective validation procedure. This is a process in which the observations by a 


\begin{tabular}{|c|c|c|c|c|}
\hline \multicolumn{2}{|c|}{ Session/Episode } & $\begin{array}{c}\text { Topic } \\
\text { The patient states that the therapist overuses the phrase }\end{array}$ & $\begin{array}{l}\text { Tipe of } \\
\text { Rupture }\end{array}$ & $\begin{array}{c}\text { Kinf of } \\
\text { Resolution }\end{array}$ \\
\hline 21 & $45 /$ feb & $\begin{array}{l}\text { The patient states that the therapist overuses the phrase } \\
\text { "I don't know if this is clear" when he speaks, and that } \\
\text { this is unnecessary and annoys her or makes her feel } \\
\text { condescended to. }\end{array}$ & Confrontation & Without Repair \\
\hline 22 & $45 / \mathrm{mag}$ & $\begin{array}{l}\text { The patient thinks the therapist and his team will not } \\
\text { waste their time with her because she does not fulfill her } \\
\text { role of speaking in the therapy, and that they will not } \\
\text { care, because she is just another patient, the same as } \\
\text { everyone else. }\end{array}$ & Confrontation & Without Repair \\
\hline 23 & 45 /giu & $\begin{array}{l}\text { The patient feels uncomfortable in the session; she does } \\
\text { not want to work therapeutically. }\end{array}$ & Confrontation & Without Repair \\
\hline 24 & 52 /gen & $\begin{array}{l}\text { The patient is very angry at the therapist, because she } \\
\text { thinks that he does not understand her explanations for } \\
\text { her lateness for the therapy. }\end{array}$ & Confrontation & Without Repair \\
\hline 25 & $52 / \mathrm{mar}$ & $\begin{array}{l}\text { The patient expresses her fear that the therapy may be } \\
\text { halted and complains about the therapist's failure to re- } \\
\text { spect the scheduling of the sessions. }\end{array}$ & Confrontation & Without Repair \\
\hline 26 & 58 / gen & $\begin{array}{l}\text { The patient feels hopeless, answers in monosyllables and } \\
\text { makes some ironic remarks, not contributing to thera- } \\
\text { peutic dialogue. }\end{array}$ & Withdrawal & Without Repair \\
\hline 27 & $69 /$ feb & $\begin{array}{l}\text { The patient is skeptical about the progress of the thera- } \\
\text { py, and complains that her efforts are fruitless. }\end{array}$ & Confrontation & Without Repair \\
\hline 28 & $69 / \mathrm{mar}$ & $\begin{array}{l}\text { The patient says she wants to end the session and leave } \\
\text { before one hour of therapy has elapsed. }\end{array}$ & Withdrawal & Without Repair \\
\hline 29 & $79 /$ feb & $\begin{array}{l}\text { The patient does not pay attention to the therapeutic } \\
\text { task, and speaks about general and superficial things. } \\
\text { The therapist tells her this and the patient denies it. }\end{array}$ & Withdrawal & Without Repair \\
\hline 30 & $81 / \mathrm{feb}$ & $\begin{array}{l}\text { The patient evades therapeutic work by narrating super- } \\
\text { ficial events. }\end{array}$ & Withdrawal & Without Repair \\
\hline 31 & $98 /$ feb & $\begin{array}{l}\text { The patient manifests her wish to end the session be- } \\
\text { cause she feels uncomfortable; she remains silent and } \\
\text { does not answer the therapist's questions. }\end{array}$ & Withdrawal & Without Repair \\
\hline 32 & $100 / \mathrm{mar}$ & $\begin{array}{l}\text { The patient confronts the therapist because she wants to } \\
\text { know what he thinks about her. }\end{array}$ & Confrontation & Without Repair \\
\hline 33 & $100 / \mathrm{feb}$ & $\begin{array}{l}\text { The patient complains that the therapist does not un- } \\
\text { derstand her and does not value the effort she makes to } \\
\text { attend the sessions. }\end{array}$ & Confrontation & Without Repair \\
\hline 34 & 119 /gen & $\begin{array}{l}\text { The patient expresses her dissatisfaction with the way in } \\
\text { which the end of the therapy was decided, and confronts } \\
\text { the therapist in this regard. }\end{array}$ & Confrontation & With Repair \\
\hline
\end{tabular}

researcher or rater are compared with the independent observations of other researchers or raters. Thus, the validation of observations is attained through consensus or agreement between these different perspectives (see Flick, 2004). With respect to the temporal delimitation of the rupture episodes, their beginnings were established by identifying the first hints of communicational rupture as listed in the manual, while their ends were established by the first hints of resolution or overcoming. Finally, ruptures in which raters did not reach agreement were excluded from the analysis.

The rupture episodes were divided into episodes with and without repair ${ }^{2}$. A repair was considered not merely as an overcoming of the rupture episode $b$ ut also as the thematic resolution of the topic that

\footnotetext{
${ }^{2}$ In this phase of the coding procedure, we did not use the 3RS coding procedure for resolutions, because this manual only allows identifying resolution strategies performed by the therapist and also only allows a global index of these strategies effectiveness in an ordinal scale. For this research, the purpose was to identify the concurrency of such repair episodes. So we developed a procedure to distinguish episodes of rupture with or without repair in a dichotomy system.
} 
provoked the rupture (see appendix 1-5). As thematic resolution is not necessarily observed during the rupture episode-for instance, it may happen later during the same session-the following criteria were established to distinguish episodes with repair from those without it: a) for episodes with repair, the criterion was that a thematic resolution or a moment of change ${ }^{3}$ related to the theme of the rupture should be observed during the same session, and $b$ ) for episodes without repair, the criterion was that a thematic resolution or a moment of change related to the rupture should not be observed during the same session (see appendix 1-5). For the coding reliability study of both kinds of episodes, we used Cohen's kappa index to assess the agre ement of two independent raters. The analysis was performed with SPSS 14.0. We used $26 \%$ of the total sample: 9 episodes randomly chosen (5 with repair and 4 without repair). The kappa value obtained was $0.78, p=0.016$. The consensual criterion for the assessment of kappa coefficients establishes that a value over 0.61 reflects an acceptable agreement level (Landis \& Koch, 1977). Additionally, as another criterion, we used the kappa coefficient obtained from the calculation of the minimum acceptable kappa value for the system of classification of episodes with and without repair. This value was calculated with FalliObs (Bakeman, McArthur, Quera, \& Robinson, 1997) following the particularities and demands that were set for the classification system: two categories, moderate variability in the simple probability of the categories, and a precision level of $95 \%$. Given these specifications, it was established that the minimum acceptable kappa level for the system was 0.78 .

\section{Data Analysis}

Two analytic strategies-confirmatory and exploratory-were used. The confirmatory one was performed to detect the presence or absence of discursive elements: nuclear utterances, monologic positions, and dialogic positions. These were identified by means of content analysis based on the relevant discursive markers and validated with an intersubjective validation procedure. These discursive markers were operationalized as follow:

\footnotetext{
3 A change episode is an interaction segment in a psychotherapeutic session in which a representational change is observed in the patient. The method for determining change episodes, derived from this definition, is based on the notion of generic change of subjective theories (Krause, de la Parra, Arístegui \& Strasser, 2006). Change in subjective theories is operationalized via generic change indicators (Krause, et al., 2006). They constitute a hierarchy of indicators that point to the specific quality of the change that marks the end of the episode labeled the "moment of change".
}

Nuclear utterances. One or more of the patient's utterances that condense the conflict present in the rupture episode and express a core position or discursive subject. That is to say, a nuclear utterance corresponds to one particular discursive subject, which is a dominant voice or position in the episode of rupture. In a previous analysis performed over the same 60 sessions used in this study (Martínez, 2011), ten discursive subjects, three for the therapists and seven for the patients, were identified (see Tables 2 and 3). In this study, nuclear utterances are thought to highlight the theme of the rupture, performed linguistically by a discursive subject.

Monologic position. The presence in the discourse of the therapist or the patient of a voice or argument that establishes a criterion or an order that determines or defines the therapeutic relationship or an aspect of it. In this therapy, these arguments are expressed by means of one of the therapist's discursive subjects (T1; see Table 3), and six of the patient's discursive subjects (P1, P2, P4, P5, P6, and P7; see Table 2).

Dialogic position. The presence in the discourse of therapist or patient voices or arguments that are an alternative to the nuclear utterance of the rupture. They amplify the spectrum of positions and offer new perspectives about the theme of the rupture. Specifically, in this therapy, these arguments are expressed by two of the therapist's discursive subjects (T2 and T3; see Table 3 ), and one of the patient's discursive subjects (P3; see Table 2).

To ensure the reliability of the coding of discursive subjects and as a complement of the intersubjective validation procedure, we used Cohen's kappa to assess the agreement of two independent raters. The analysis was performed with SPSS 14.0. We used $30 \%$ of the total sample. For kappa index estimation, we used a criterion that considers minimal acceptable values (MAV) for discursive subjects grouped in three variability categories: High variability (discursive subjects T3 and P1), moderate variability (P2, P5, and $\mathrm{P} 7)$, and low variability (T1, T2, P3, P4, and P6). FalliObs software was used to calculate the minimum expected values (Bakeman, Quera, McArthur, \& Robinson, 1997), and a precision ${ }^{4}$ level of $80 \%$ was defined (MAV: High variability 0.2 , moderate variability 0.3 , low variability 0.36 ). According to each category variability, all obtained values are within an acceptable agreement index (Landis \& Koch, 1977) except for discursive subject P2 [T1 $(\mathrm{k}=0.72, \mathrm{p}=0.000) ; \mathrm{T} 2$ $(\mathrm{k}=0.41, \mathrm{p}=0.015) ; \mathrm{T} 3 \quad(\mathrm{k}=0.82, \mathrm{p}=0.000) ; \mathrm{P} 1$ $(\mathrm{k}=0.64, \mathrm{p}=0.000) ; \mathrm{P} 2 \quad(\mathrm{k}=0.24, \mathrm{p}=0.081) ; \mathrm{P} 3$

\footnotetext{
${ }^{4}$ Precision is the conditional probability that when an event is predicted to be in class $\mathrm{C}$, it truly belongs to this class (Bakeman et al., 1997).
} 
$(\mathrm{k}=0.94, \quad \mathrm{p}=0.000) ; \mathrm{P} 4 \quad(\mathrm{k}=0.45, \mathrm{p}=0.005) ; \mathrm{P} 5$ $(\mathrm{k}=0.44, \mathrm{p}=0.009) ; \mathrm{P} 6 \quad(\mathrm{k}=0.38, \mathrm{p}=0.010) ; \mathrm{P} 7$ $(\mathrm{k}=0.41, \mathrm{p}=0.007)]$.

The second analytic strategy was of an exploratory character: its aim was to reveal the presence or absence of linguistic elements that take part in the construction of the intersubjective field. Specifically, therapist-patient discourse was coded according to the use of person markers such as pronouns, proper nouns, possessive marks, indeterminate subjects, and instances of passive voice, etc. All of this, of course, is in the Spanish language. The aim of this analysis was to see how the participants labeled themselves during the discourse with regard to their own subjectivity. Or, from a different perspective, how both participants made their own subjectivity appear or disappear from the discourse. It was thought that the presence of linguistic markers that stress objectivity (i.e., those which make subjectivity disappear from the dialog, would allow us to explore the second hypothesis in depth. Concurrently, it was expected that the presence of linguistic markers that highlight subjectivity would allow us to test the third hypothesis.

Table 2a. Patient's Discursive Subjects

\begin{tabular}{llll}
\hline $\begin{array}{c}\text { Discursive } \\
\text { Subject }\end{array}$ & Discursive Signs & $\begin{array}{c}\text { Characterization and } \\
\text { Utterances }\end{array}$ & Excerpts of Utterances \\
\hline & $\begin{array}{l}\text { Pronominals + predica- } \\
\text { tive attributes: }\end{array}$ & $\begin{array}{l}\text { P: When I made the decision to come here (.) it was because of that } \\
\text { and actually to be::: (3.0) because my children need me and are grow- } \\
\text { ing up they are WATCHING ME (8.0) and it's for THEM that I'm } \\
\text { doing this (S1E1) }\end{array}$
\end{tabular}

The selfless person or the martyr (monological - They need me. position)

- I skipped stages

- I wouldn't leave without them

- I had to be my siblings' mother
A position of frustration with life, without any enjoyment, sacrificing everything for others: "I make sacrifices so that others can enjoy and live well." Anger and depression are the predominant emotions.
P:...It's just that:: $<$ I don't know maybe $>$ I like that sensation of the kids because maybe I skipped stages too (...) which may have been, well adolescence as well (.) so those are things I lack and::: and when one sees that (.) it seems fun:: it seems:: (.) more than fun emotional, nice (S60E2)

\section{P2. 1.Pronominals + predic- ative attributes:}

The watched and limited person (prisoner) (monological position)
P: ...I always have trouble because (.) there are things that influence me more than others to make a decision.

For instance, if I go to work, I need to leave my baby (.) alone and that Position which blames others for her situation. Others watch her and do not let her be independent: "They control me, and they interrogate me in a tough and harsh way." They do not listen to her or help her; instead, they "put her down," they make her feel she is "in a lower category." The therapist also participates in this. Anger and anxiety predominate. causes (.) problems (.)with one's couple = How can you go out? (.) The child will be alone (.) and stuff like that (.) and that he's so young:: and that you don't need anything:: $(3,0)$ nothing so to speak $(4,0) \downarrow$ because one still needs one's independence (S2E1) 


\section{Results}

\section{Confirmatory Results}

Nuclear utterances. Both kinds of episodes of rupture, with and without repair, showed nuclear utterances. That is to say, the first hypothesis was confirmed. In the rupture episodes with repair, $50 \%$ of the patient's nuclear utterances corresponded to the discursive subject named The Zombie (P6; see Table 2); $30 \%$ of them belonged to the discursive

Table 2b. Patient's Discursive Subjects subject named The Independent and Distrustful Person (P4; see Table 2); and the smallest percentages corresponded to The Quarrelsome Person (P7) and The Guilty Person (P2), with $10 \%$ each. In the rupture episodes without repair, $45.8 \%$ of the patient's nuclear utterances corresponded to the discursive subject named The Zombie (P6; see Table 2); $20.8 \%$ of them belonged to the discursive subject named The Independent and Distrustful person (P4; see Table 2); and $33.4 \%$ corresponded to The Quarrelsome Person (P7). There were no statistical

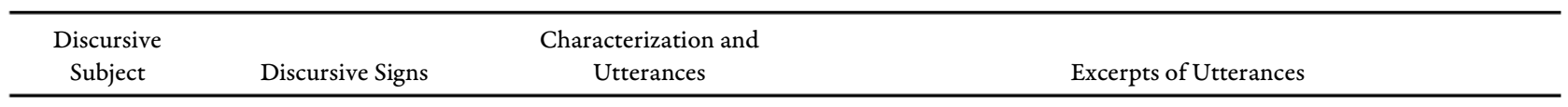

1. Pronominals + predicative attributes:

\section{what $I$ think}

P3. The person responsible for her own life (dialogical posi- - I like it tion)
Position that acknowledges its responsibility in problems, together with a desire to change and ability to do so. Others, including the therapist, can help, protect, and stimulate her in this change. Hope and optimism predominate. This position considers contrary voices and converses with them.

P: I don't know maybe if I think about it:: (.) with more:: (2.0) not so much with my brain::: that we have created a bond like this and::: I mean::: something has been imposed:: not an obligation but a, a part of my::: life um::: coming here, talking about (.) personal:: issues of mine, issues that sometimes (.) that I can't discuss with anybody:: or that nobody really cares about::: I can talk about them here (S32E2)

P: "I started::: saying, telling him that what he says to me is not that important (...) what I think and what I want to do is more important" $(\mathrm{S} 18 \mathrm{E} 1)$

P: Not much or nothing, or::: or maybe I've had it sometime, once maybe::: (2.0) not many times really, right now really (3.0) it's here where I feel::: where I identify more with myself and I, it's like I can see myself in this mirror (laughs) (S39E1)

P: I hadn't seen it that way, I mean, I hadn't analyzed it that way I had taken the other skeptical position of not trusting the other person due to a matter of... (S115E3)

1. Pronominals + predicative attributes:

- I don't feel anything for anybody.

P4. The independent (autonomous) and distrustful person. (monological position)
Position which sustains the idea that she does not need anybody and does not care about other people. The patient thinks other people do not care about her either. From this perspective, she does not need therapy and the therapist does not seem trustworthy. Anger, distrust, or emotional detachment predominate. "I can live completely by myself." Others are not to trust, because "they always have another face, they hide something." This is eminently monological: there is only one image of the other.
P: It wasn't::: (.) the person::: (.) I mean:: (.) somebody you could tell um:: anything or::: they interact with you in a:: different way, I mean one side behaves like this and the other side:: (...) I've always believed that in people there's a duality (S2E2)

P: [The thing is I've already] seen it all with everything that happen to me (...) it's that::: nothing shocks me anymore because of people who:: (.) say something and then:: don't do it, who:: or start something and don't complete it::: (...) so it's like I already have antibodies with the things people do $=$

(S52E2)

P: That I don't feel anything for anybody $\downarrow$ for anybody (2.0) in those terms I mean (5.0) but:: I also think that it's not good (.) to be like that I mean, it happens for a reason, it's:: it's something (3.0) because:: well all human beings, EVEN ANIMALS have:: (2.0) their desires *se, sexual their* their um, um they have:: I don't know well a very natural thing THAT, so to speak >is said to be natural< but it isn't natural for me I mean for me um:: it's like a complex of mine $\downarrow$ (S12E2)

\footnotetext{
I don't think you

care at all
} 
differences between episodes with and without repair regarding the type and frequency of the therapist's discursive subjects expressed in the nuclear utterances, $\mathrm{P} 2, \mathrm{X}^{2}(1, \mathrm{~N}=1)=0, \mathrm{p}=1 ; \mathrm{P} 4, \mathrm{X}^{2} \quad(1$, $\mathrm{N}=8)=0.33, \mathrm{p}=0.57 ; \mathrm{P} 6, \mathrm{X}^{2}(1, \mathrm{~N}=16)=0.05, \mathrm{p}=0.82$; $\mathrm{P} 7, \mathrm{X}^{2}(1, \mathrm{~N}=9)=2.47, \mathrm{p}=0.12$.

Monological and dialogical positions. No statistical differences were found between episodes of rupture with and without repair with respect to the presence of monologic (with $\mathrm{N}=10$, without $\mathrm{N}=24$ ) or dialogic positions (with $\mathrm{N}=9$, without $\mathrm{N}=20$ ) $\left(\mathrm{X}^{2}=0.02,1 \mathrm{df}, \mathrm{p}=0.88\right)$ in each one of these episodes. So, the second and third hypotheses were not confirmed. Nevertheless, a significant difference was found in a post hoc comparison of monologic and dialogic positions in the therapist's and the patient's utterances in episodes of rupture with and without repair. While the therapist's utterances presented the same proportion of dialogic positions in both types of episodes $\chi_{2}(1, \mathrm{~N}=34)=0.25, p=0.62$, the patient's utterances presented a higher propor-

Table 2c. Patient's Discursive Subjects

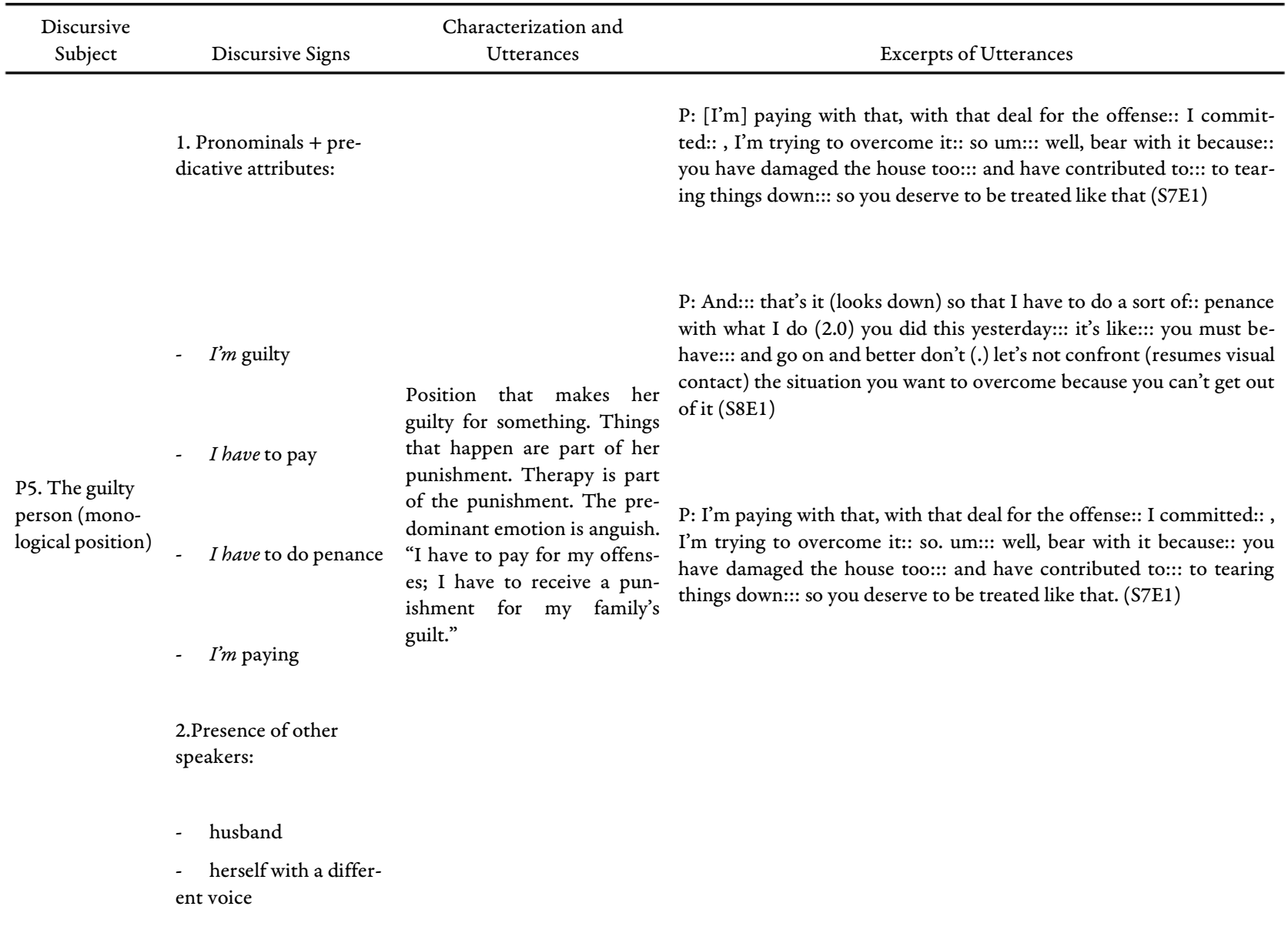

1. Pronominals + predicative attributes:

P6. The person who is dead in life (zombie) (monological position)
Position which sees life passively and change as impossible. There is no way out: life is monotonous and goes nowhere, and she needs others to guide her and tell her what to do. The main emotions are depression, hopelessness, fear, and abandonment. "Therapy doesn't work for me, because I'm a hopeless case, I'm like this and I'm not going to change." "This is my personality and nobody can do anything about it."
P: That's true (4.0) hhh (8.0) that's true because I don't really know where this is going $\uparrow$ I mean (.) I don't get it, because living like this like a zombie, a bird (wipes tears), it's boring really it's not very, (2.0) it's like::: (2.0) living just for the sake of living... (S7E2)

P: (8.0) No, I think I don't $\downarrow$ (.) no, I don't want to waste your time $\uparrow$ or waste mine here $\uparrow$ sulking (S26E4)

P: "I would just like to commit suicide and never:: never hear about anything else $(16.0)<$ I have no reasons to do things or I don't want to accept that I can do things and: I can also (.) destroy things $>$ (cries) (23.0) (S17E2) 
tion of dialogic positions in episodes of rupture with repair $\chi_{2}(1, \mathrm{~N}=34)=14.07, p=0.00$.

\section{Exploratory Results}

Table 4 depicts emergent categories of linguistic markers. The therapist and the patient used all of them in both types of rupture episodes. Three of the personal markers found in the exploratory analysis are signs of subjectivity (FPS, FPP, SPS; see Table 4), while only one of them makes subjectivity disappear (IP; see Table 4).

After performing comparisons considering the total of linguistic markers, episodes without repair showed an extensive use of the first person plural (FPP), $\chi_{2}(1, \mathrm{~N}=1400)=4.62, p=0.03$. On the other hand, in the episodes with repair, the indeterminate person (IP) was widely used, $\chi_{2}(1, \mathrm{~N}=1400)=7.37$, $p=0.01$. These results show that, in ruptures without repair, intersubjectivity was summoned more often than in those with repair. In contrast, episodes with repair stressed objectivizing more than episodes without repair.

No significant statistical differences were found in the use of the FPP by the therapist and the patient in episodes of rupture with ( $\mathrm{T} 93.5 \%$; $\mathrm{P}$ $6.5 \%$ ) or without repair ( $\mathrm{T} 96.2 \%$; $\mathrm{P} 3.8 \%$ ), $\chi_{2}$ (1, $\mathrm{N}=151)=0.53, p=0.47$. Nevertheless, it was the therapist who used this type of person marker more frequently (95.4\%), irrespective of the type of rupture episode, $\chi_{2}(1, \mathrm{~N}=1400)=58.24, p=0.00$.

Besides, the patient used the IP marker more frequently in episodes of rupture with repair $(64.2 \%)$ than the therapist, whereas the therapist used it more in episodes without repair (64.7\%), 凶2 $(1, \mathrm{~N}=104)=8.66, p=0.000$. Nevertheless, in these last episodes it was also the patient who presented subjectivity markers by using the FPS more (49\%) than the therapist $\chi_{2}(1, \mathrm{~N}=721)=6.68, p=0.01$.

\section{Emergent Model}

Finally, an emergent conceptual model was inferred on the basis of the results of the confirmatory and exploratory analyses (see Figure 2).

Table 4. Number (and percentage) of personal markers in episodes of rupture with and without repair

\begin{tabular}{llcccc}
\hline $\begin{array}{l}\text { Personal } \\
\text { Markers }\end{array}$ & $\begin{array}{l}\text { With } \\
\text { Repair }\end{array}$ & Without Repair & $d f$ & $X^{2}$ & $p$ \\
\hline FPS & $284(52.7)$ & $437(50.8)$ & 1 & 0.50 & 0.48 \\
FPP & $46(8.5)$ & $105(12.2)$ & 1 & 4.62 & $0.03^{* *}$ \\
SPS & $156(28.9)$ & $268(31.1)$ & 1 & 0.75 & 0.39 \\
IP & $53(9.8)$ & $51(5.9)$ & 1 & 7.37 & $0.01^{* *}$ \\
\hline
\end{tabular}

\begin{tabular}{lcc}
\hline$N$ & 539 & 861 \\
\hline Note. FPS=First Person Singular; FPP=First Person Plural;
\end{tabular}

SPS $=$ Second Person Singular; IP $=$ Indeterminate Person. ** $=0.01$.

The model assumes that, in a rupture episode, with or without repair, it is possible to identify a

Table 2d. Patient's Discursive Subjects

\begin{tabular}{|c|c|c|c|}
\hline $\begin{array}{l}\text { Discursive } \\
\text { Subject }\end{array}$ & Discursive Signs & $\begin{array}{c}\text { Characterization and } \\
\text { Utterances }\end{array}$ & Excerpts of Utterances \\
\hline $\begin{array}{l}\text { P7. The quar- } \\
\text { relsome person } \\
\text { (monological } \\
\text { position). } \\
\text { “'Achorada," } \\
\text { Chilean adjecti- } \\
\text { ve that describes } \\
\text { a person who } \\
\text { acts in a hostile } \\
\text { way and who } \\
\text { often argues } \\
\text { with others ]. }\end{array}$ & $\begin{array}{l}\text { - I would like you to } \\
\text { tell me } \\
\text { - it happens to you } \\
\text { - I want to know who } \\
\text { you are } \\
\text { - I want to know } \\
\text { when } \\
\text { - don't you fall }\end{array}$ & $\begin{array}{l}\text { Position which seeks sym- } \\
\text { metry in the therapeutic rela- } \\
\text { tionship. Voice that seems } \\
\text { angry at times or making fun } \\
\text { of others. Position which } \\
\text { tends to interrogate the } \\
\text { other, crack jokes, or con- } \\
\text { front him with respect to a } \\
\text { given situation. "I want to } \\
\text { know who I'm dealing with, } \\
\text { who my doctor is." "It's my } \\
\text { right to know." }\end{array}$ & $\begin{array}{l}\text { P: I would like the conversation to be different:: I should ask you } \\
\text { sometimes (...) how you interact with your family::: (...) if you have a } \\
\text { FAMILY or if you don't ( } 2.0 \text { ) about YOUR JOB or if it's always like } \\
\text { this (.) and:: if you don't get bored:: of looking at people who are si- } \\
\text { lent in front of you all the time (laughs) (S12E1) } \\
\text { P: But I think it probably happens to everyone once in a while, every } \\
\text { once in a while } \downarrow \text { has it never happened to you? (S26E3) } \\
\text { P: (aughs)] What a problem I'm behind a mirror and about twenty } \\
\text { people are looking at me (laughs) }{ }^{*} \text { They're listening to me!* }(.)^{*} \text { That's } \\
\text { one HELL of a problem!* } \\
\text { It would be like being at the National Stadium* if you had me HERE } \\
\text { in the middle here" (S15E2) }\end{array}$ \\
\hline
\end{tabular}

Note. The codes in parentheses at the end of each extract first indicate the session number from which the paragraph was extracted and then the number of the episode within that session. For example, S1E1 refers to session 1, episode 1. 
Table 3a. Therapist's Discursive Subjects

\begin{tabular}{cc}
\hline $\begin{array}{c}\text { Discursive } \\
\text { Subject }\end{array}$ & $\begin{array}{c}\text { Charaterization } \\
\text { and utterances }\end{array}$ \\
\hline
\end{tabular}

\author{
1. Pronominals + \\ predicative attribu- \\ tes:
}

- I told you

T1. The teacher (monological posi- - I would say that tion)
Position that sees life from the authority of someone who knows the truth about things and teaches. It is based on psychotherapy theory or on explanations about its techniques. From this position, the therapist describes events, explores situations, asks rhetorical questions and interprets. "This thing that happens to you here also happens to you in other places, you have a behavior style or pattern independent from myself"; "it seems that YOU got mad at me." It does not integrate other voices or positions of his own or of the patient.

\section{Utterance extracts}

T: I'd say that rather than discussing:: whether this helps me, the experience that we have here is that when someone starts feeling free to talk about all this that goes through one's head $\downarrow$ being able to interact more fluently like we're doing now, the idea is that it's useful for the patient $\downarrow$ (S12 E2)

T: Look, I think that when I told you that I can tell you how old I am and:: if I have children or if I'm married or not (.) .hhh actually look, I think that what I hhh. try to explain there is that um::(3,0) it's a type of question connected to a fact of reality (.) right, I mean, obviously, I mean that um:: it's your right to wonder who I am, what I do, right, outside these four walls, right? (.) so what I'm telling you is that the question seems legitimate to me (.) what I'm explaining to you is that from the point of view of the work method (.) of the work method (.) it's not that I can't tell you where I live, what I do, maybe I could tell you things, other things too (.) it's that, what I'm explaining to you is that the work method, which we have here, um::: (S33E1)

$\mathrm{T}:(. .$.$) because one might say, and why don't they help y-$ ou? (2.0) I don't know if as the only figure, but like a sort of joint thing, shared I think $\downarrow$ (2.0) it's like a representation of how people feel better when we start acting like this (2.0): sometimes one helps, sometimes others help you (.) Sometimes one feels weak and the other feels strong (.) Sometimes the other person is weak and one is strong, do I make myself clear? And it's how we understand a more dynamic form of (...) $\downarrow$ which in turn is more like (.) it makes one feel less locked up (S57E2)

$\mathrm{T}$ : "....and in that case of course, in that case it does make sense to see whether:: (.) Someone else, for instance, me here (.) can give you an opinion, which sometimes we call interpretation:: a way of understanding, somebody else who has a certain idea of what I think is going on. I'm not sure if that's clear? (S26E4)

\footnotetext{
- when a patient

- what I'm telling you

- what I'm explaining

to you

- the method we have

here

- do I make myself

clear?

- let's say

- we call it like that

here
}

topic of the communication rupture or breakdown that confronts or distances the therapist and the patient. At the same time, and from a dialogic point of view, within an episode of rupture it is possible to identify nuclear utterances in the patient, which synthesize central aspects of the discursive subject 
Table 3b. Therapist's Discursive Subjects

\begin{tabular}{|c|c|c|c|}
\hline $\begin{array}{c}\text { Discursive } \\
\text { Subject }\end{array}$ & & $\begin{array}{l}\text { Charaterization } \\
\text { and utterances }\end{array}$ & Utterance extracts \\
\hline $\begin{array}{l}\text { T2. The pro- } \\
\text { poser (dialogi- } \\
\text { cal position) }\end{array}$ & $\begin{array}{l}\text { - I think that } \\
\text { - my idea is that } \\
\text { - you're conveying to } \\
\text { me the idea that } \\
\text { - maybe I haven't } \\
\text { been } \\
\text { - What do you think? } \\
\text { - What does this } \\
\text { make you feel? }\end{array}$ & $\begin{array}{l}\text { Position which sees the } \\
\text { other's life from true igno- } \\
\text { rance and honest curiosity, } \\
\text { a desire for knowledge. It } \\
\text { is supported by what the } \\
\text { other says or transmits. } \\
\text { From this perspective, the } \\
\text { therapist describes events, } \\
\text { asks authentic questions, } \\
\text { and proposes other per- } \\
\text { spectives to the other par- } \\
\text { ty. The therapist seeks to } \\
\text { increase the amount of } \\
\text { dialogue and favors the } \\
\text { joint creation of answers. } \\
\text { This position intends to } \\
\text { integrate the therapist's or } \\
\text { the patient's statemens. }\end{array}$ & $\begin{array}{l}\text { T: I'm saying this because I intended to show you a bit of } \\
\text { how it could be different for us here to understand for ex- } \\
\text { ample that::: the responsibility of this thing that happens } \\
\text { is your husband's::: your children's::: and it's due to how } \\
\text { they treat you (.) or that maybe we are starting to look at } \\
\text { your responsibility }(.) \text { in the decisions you have made in } \\
\text { your:: life (S15E1) } \\
\text { T: Maybe it's partly related to that, I think or maybe not } \\
\text { completely, the feeling you have that the experience of } \\
\text { coming here for me to see you... there's something that } \\
\text { you feel that maybe I haven't given you the tools to deal } \\
\text { with this situation in a more efficient way (.) to solve it in a } \\
\text { better way ( } 29 \mathrm{E} 1 \text { ) }\end{array}$ \\
\hline
\end{tabular}

\begin{abstract}
1. Pronominals + predicative attributes:
\end{abstract}

- this thing I'm feeling

T3. The sensitive person (dialogical / monological)

- these sensations that you

- I was touched by what you

- your voice sounds

- it touches me
T: You know, so I have a sensation right now which I'd like to share with you (.) because:: (.) so for example, if the emotion that you transmit to me and which makes me:: makes me want to help (S1E2)

Position which highlights the importance of the sensory and emotional experience, here and now, of the encounter with the other. From this position, the therapist emphasizes bodily sensations and shows nonverbal elements and his feelings. It is a position that supports the other voices, and is more dialogical or monological depending on the function it performs in a discursive content.
$\mathrm{T}$ : Okay $(4,0)$, these sensations that you have conveyed to me, these experiences of yours that I:: that we can share here (.) are they current experiences or have things always been like this? Has your life been a little like this? (S2E1)

T: M-hm (10.0). hhh Look, it's like right now I was touched by what you said (2.0) and I have the impression that you were moved as well (S44E4)

$\mathrm{T}$ : Sometimes you start sessions like this with a voice that I have to say, come again? Because I can't hear you, and it's more frequent for me to hear you by the end of the session, because your voice is louder::: and it's as if something like this was appearing" (S16E2)

\footnotetext{
Note. The codes in parentheses at the end of each extract first indicate the session number from which the paragraph was extracted and then the number of the episode within that session. For example, S1E1 refers to session 1, episode 1.
} 
taking part in the conflict and acting in it. In this scenario, two strategies for overcoming the rupture were analyzed: 1) the use of monologic positions and 2) the use of dialogic positions.

The assumption is that both strategies are employed by the therapist as well as the patient, in order to regulate each other and to reduce the conflictive tension that has broken the communication between them. The inclusion of a monologic position has the effect of objectivizing the relationship by obliterating any subjectivity: When subjectivity disappears, tension disappears as well, and the rupture is overcome. Nevertheless, this resolution does not repair the relationship between the subjects because there are no subjects to repair. A relationship with no tension whatsoever does not consider the role of the other-of alterity-as a requirement for establishing the intersubjective field.

The second overcoming strategy-the inclusion of a dialogic position-also used by both the therapist and the patient, seems to refill the relationship with subjectivity. Calling other arguments or discursive subjects seems to have the effect of dividing the tension between different perspectives or different positions of the self. Moreover, it seems that such a repairing strategy contributes to the mutual regulation process insofar that it has self-regulatory effects on the addressee. This strategy not only makes it possible to overcome the rupture but also to repair it.

The results show that episodes of a rupture with a repair also presented the strategy of using monologic positions, probably because it must be one of the most common strategies to overcome a conflict, seeking the objectivity or the truth of a powerful and apparently neutral judge. But it seems that only the inclusion of dialogic positions is able to repair the relationship.

Besides, the more exploratory results show that the so-called subjectivizing and objectivizing personal markers were present in both types of episodes. However, significant differences were observed between the episodes of a rupture with and without repair: The patient's use of the FPS as a marker of subjectivity was much higher in episodes with repair than in those without repair. Instead, the therapist used the FPS more often as a subjectivity marker in episodes without repair. Also, the therapist used the FPP more frequently as a linguistic marker of intersubjectivity in both types of episodes compared to the patient. Concerning IP, considering it as an objectivizing personal marker that makes subjectivity disappear, this was used more often by the patient in episodes with repair, while the therapist used it more in episodes without repair.

Given the above results, subjectivization is highlighted as an important repair strategy and, at the same time, objectivization shows a differential use as a linguistic marker by the participants to contribute to repair. Specifically, the patient would be more likely to use indeterminate personal markers as a strategy to hide subjectivity in episode ruptures with a repair.

Thus, considering both the confirmatory and the exploratory results, it could be said that when the patient employs a dialogic position and linguistic subjectivity markers there would be higher probability of a repair of the rupture than when these are used only by the therapist. Indeed, in both types of episodes the therapist employed subjective strategies, but our hypothesis was that what might make the difference is the patient's willingness and openness to this invitation to repair the relationship.

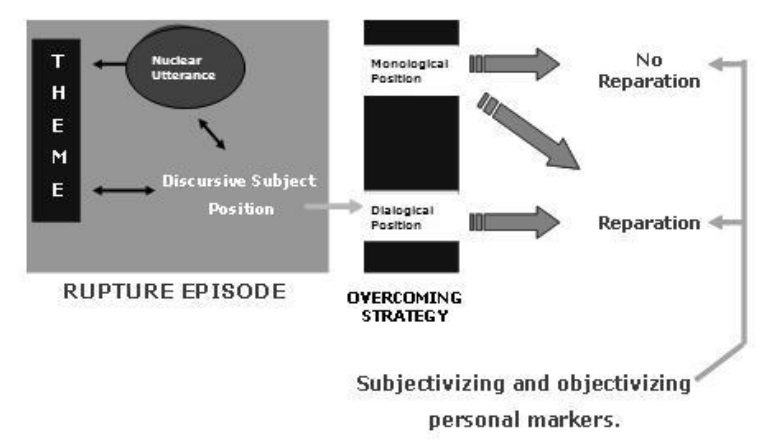

Figure 2. Emergent model of rupture repair from a dialogic Perspective.

\section{Discussion}

The confirmatory and exploratory results of this study not only allowed for the emergence of a model that permits inferring the dialogic role of the repair of the patient-therapist relationship but also showed that mutual regulation in episodes of rupture with a repair is different from that in episodes without a repair.

The emergent model of rupture repair from a dialogic perspective suggests a conceptual difference not mentioned in the literature: that overcoming and repairing rupture moments are different in nature. Both are the result of a regulatory process, but in theoretical and practical terms there could be an important difference, and the evidence shown here supports this. The idea of some authors that the elaboration of the rupture in the alliance can foster a therapeutic change (Luborsky, 1994; Safran, Muran, \& Samstag, 1994) is better backed by the notion of repairing the rupture than by that of overcoming it. A notion often found in the literature is that a moment of rupture is a chance to explore the deepest conflictive and relational aspects of patients (Safran \& Muran, 1996, 2000; Sommerfeld, Orbach, Zim, \& Mikulincer, 2008; Viklund, Holmqvist, \& Zetterqvist, 2009), but the authors 
are less precise when pointing out which therapeutic actions will permit such an exploration and subsequent change. In this sense, although in this study we used conceptualizations and part of the coding system of Safran and Muran (EubanksCarter et al., 2008), the model we proposed moves toward a procedural consideration of the rupture of the alliance and its resolution, that is to say, stressed the interactional elements and specific therapist actions that could mediate a rupture and its possible repair. In a recent study, Viklund, Holmqvist, and Zetterqvist (2009) found three different methods therapists used to handle disagreements in psychotherapy sessions: (a) establishing a shared understanding by inviting the patient to elaborate his or her point of view; (b) establishing a shared understanding by defining the therapist's own point of view as more relevant than the client's, and (c) avoiding orienting the conversation toward the client's disagreement cues. Although the authors did not probe the comparative results of these strategies, the first of them resembles the dialogic strategy that stimulates co-participation in the repair of the rupture. The second is similar to the strategy of the monologic position used by the therapist, whereas the third can be likened to strategies to overcome but not repair the therapeutic relationship. All of these were observed in our study.

The emergent model of the rupture regarding the alliance repair stresses, from a dialogic perspective, that repairing the rupture is not the same as overcoming it. The latter is included in the former, but the opposite does not seem to be true. This means that not necessarily does overcoming a rupture leads to relationship repair. The latter involves, according to our results, the use of dialogic arguments to consider the presence of discursive subjects opposed to that which is the nucleus of the relational conflict. Furthermore, reparation implies distinguishable elements, which can foster therapeutic change. Among these elements, an active participation of the patient seems to be essential, either by invoking objectivity through a monologic position and indeterminate person markers or by invoking subjectivity, including in the dialogic positions. Another element that seems to foster the repair is the therapist's reincorporation of subjectivity. In addition, the results revealed that episodes of rupture with a repair were not characterized only by the essential presence of a dialogic position of the patient, which permitted dialogue and facilitated the help relationship, but also by the maintenance of the tension between opposite, discursive subjects, either within the intramental space or between the speakers. Bromberg (2004) has pointed out the importance of constructing a relational space in psychotherapy to make it possible to think about what happens to the patient and the therapist, as well as between them, which is expected to foster the per- ception of other voices. In a similar direction, Ogden (2004) suggested the relevance of the therapist's actions aimed at tracking the dialectical movement of individual subjectivity and the space that the author calls the "analytic third," an unconscious and intermental space where the participants' subjectivities are mutually recognized and transformed. Some literature in contemporary psychoanalysis to underscore the importance of mutual recognition as essential, for example, in understanding the trauma, where domination of monologic sadism makes disappear the other, who surrenders to his desire for recognition (Ghent, 1990). We also emphasize that it is essential to recognize the multiple aspects of the self as own, avoiding the domination of one position over the others.

Based on our findings, we can state that the core issue in the resolution of ruptures seems to be dealing with the tension between the participants. While the regulatory strategy of calling a monologic position makes the tension disappear, the regulatory strategies invoking subjectivity refill the relationship with tension. This tension becomes an opportunity for the therapist to explore new positions, integrating the alterity that makes change possible (Benjamin, 1988; Leiman, 2004). Nevertheless, this exploration always occurs under the limits that the patient imposes, and these delimit a secure and trusted zone in the relationship with the therapist. In a recent contribution, Ribeiro and colleagues (2012) proposed a system that allows coding the degree of therapeutic collaboration; the authors highlighted the relevance of the ability of the therapist to work within what has been called a "therapeutic zone of proximal development (TZPD)." This constitutes a space for the patient's potential change in which the therapist can work, though considering a safety zone and a tolerable risk zone because beyond this point the patient could invalidate any intervention by the therapist. Thus, as we have mentioned above, the dialogic tension must not break the relationship. In other words, as an old saying goes "not so hot that it burns but not so little that's it cold".

The main limitation of the study presented in this article concerns the possibility of generalizing its findings to all types of psychotherapies. Since it is a single-case analysis, there may be doubts about the chances of applying this emergent model to other psychotherapeutic processes of different approaches and theoretical orientations, to dyads of the same or different sex, or to patients with other diagnoses. For this reason, the findings presented must be interpreted cautiously concerning their external validity. Nevertheless, the results presented lead to the description of a preliminary comprehensive model. Such a model could make it possible to observe, in the patient-therapist dyad's discourse, the regulatory processes involved in rupture repair. 
Indeed, as we have mentioned above, this case study allowed us to construct a comprehensive and exploratory model of rupture repair. Nevertheless, more studies are necessary to strengthen this model by continuing to test its hypotheses. The microprocess analysis that made these results possible is a very time-consuming method, but it allowed us to collect relevant data about the therapeutic dialogue and the micro-relationship. We believe that this effort is necessary for expanding our knowledge about the therapeutic alliance and expect this study to be a step in that direction. Even more, currently we have developed a research (Martínez, Krause, Tomicic, Altimir, \& Pérez, 2014) on interactive regulation that not only includes verbalized and symbolic data but also nonverbal and sub-symbolic ones such as vocal quality (Tomicic \& Martínez, 2011; Tomicic et al., 2014; Tomicic, Martínez, \& Krause, 2014) and facial behavior in rupture and other relevant episodes.

\section{References}

Altimir, C., Krause, M., de la Parra, G., Dagnino, P., Tomicic, A., Valdés, N., ..., \& Vilches, O. (2010). Clients', therapists' and observers' perspectives on moments and contents of therapeutic change. Psychotherapy Research, 20(4), 472-487. doi: $10.1080 / 10503301003705871$

American Psychiatric Association. (1994). Diagnostic and Statistical Manual of Mental Disorders (4th ed.). Washington, DC: Author.

Bakeman, R., Quera, V., McArthur, D., \& Robinson, B. F. (1997). Detecting sequential patterns and determining their reliability with fallible observers. Psychological Methods, 2, 357-370. doi: 10.1037/1082-989X.2.4.357

Bakhtin, M. (1986). Speech genres and other late essays. Austin: University of Texas Press.

Bakhtin, M. (2003). Problems of Dostoevsky's poetics. Minneapolis: University of Minnesota Press.

Beebe, B. (2006). Co-constructing mother-infant distress in face-to-face interactions: Contribution of microanalysis. Infant Observation, 9(2), 151-164. doi: 10.1080/ 10481889409539027

Beebe, B., \& Lachmann, F. (2002). Infant research and adult treatment: Co-constructing interactions. Hillsdale, NJ: Analytic Press.

Beebe, B., Knoblauch, S., Rustin, J., \& Sorter, D. (2005). Forms of intersubjectivity in infant research and adult treatment: $A$ system view. In B. Beebe, S. Knoblauch, J. Rustin, \& J. D. Sorter (Eds.), Forms of intersubjectivity in infant research and adult treatment (pp.1-28). New York, NY: Other Press.

Benecke, C., Peham, D., \& Banninger-Huber, E. (2005). Non-verbal relationship regulation in psychotherapy and change. Psychotherapy Research, 15,(1) 81-90. doi: $10.1080 / 10503300512331327065$

Benjamin, J. (1988). The bonds of love: Psychoanalysis, feminism, and the problem of domination. New York: Pantheon.

Benjamin, J. (1995). Like subjects, love subjects. New Haven, CT: Yale University Press.

Blatt, S. J. (2008). Polarities of experience. Washington, DC: American Psychological Association.

Brandchaft, B., Doctors, S., \& Sorter, D. (2010). Toward an emancipatory psychoanalysis. Brandchaft intersubjective vision. New York, NY: Routledge.
Bordin, E. (1994). Theory and research on the therapeutic working alliance: New directions. In A. O. Horvath \& L. S. Greenberg (Eds.), The working alliance: Theory, research, and practice (pp. 13-37). New York, NY: Wiley.

Bromberg, P. (2004). Standing in the spaces. The Multiplicity of Self and the Psychoanalytic Relationship. In $\mathrm{H}$. Hermans \& G. Dimaggio (Eds.), The dialogical self in psychotherapy (pp.138-151). New York, NY: Taylor \& Francis Group.

Colli, A., \& Lingiardi, V. (2009). The collaborative interactions scale: A new transcript-based method for the assessment of therapeutic alliance ruptures and resolutions in psychotherapy. Psychotherapy Research, 19(6), 718-734. doi: $10.1080 / 10503300903121098$

Echávarri, O., González, A., Krause, M., Tomicic, A., Pérez, C., Dagnino, P., . . . \& Reyes, L. (2009). Cuatro terapias psicodinámicas breves exitosas estudiadas a través de los indicadores genéricos de cambio [Four successful psychodynamic psychotherapies studied through generic change indicators]. Revista Argentina de Clínica Psicológica, $X \operatorname{VIII}(1), 5-19$.

Elliot, R. (1984). A discovery-oriented approach to significant events in psychotherapy: Interpersonal process recall and comprehensive process analysis. In L. Rice \& $\mathrm{L}$. Greenberg (Eds.), Patterns of change (pp. 249-286). New York, NY: Guilford Press.

Eubanks-Carter, C., Muran, C., Safran, J., \& Mitchell, A. (2008) Rupture resolution rating system. Unpublished guide, Beth Israel Medical Center, NY, USA.

Ghent, E. (1990). Masochism, submission, and surrender. Contemporary Psychoanalysis, 26, 108-136.

Gonçalves, M., \& Guilfoyle, M. (2006). Dialogism and psychotherapy: Therapists' and clients' beliefs supporting monologism. Journal of Constructivist Psychology, 19, 251271. doi: 10.1080/10720530600691723

Gonçalves, M., Matos, M., \& Santos, A. (2009). Narrative therapy and the nature of "innovative moments" in the construction of change. Journal of Constructivist Psychology, 22, 1-23. doi: 10.1080/10720530802500748

Greenberg, J. (1995). Psychoanalytic technique and the interactive matrix. Psychoanalytic Quarterly, 64, 1-22.

Hermans, H. J. (1996). Voicing the self: From information processing to dialogical interchange. Psychological Bulletin, 119(1), 31-50. doi: 10.1037/0033-2909.119.1.31

Hermans, H. J., \& Hermans-Konopka A. (Eds.) (2010). Dialogical self theory. Positioning and counter-positioning in a globalizing society. Cambridge, United Kingdom: Cambridge University Press.

Hermans, H. J., \& Lyddon, W. J. (2006). Counselling as multivoiced and dialogical. Counselling Psychology Quarterly, 19(1), 1-4. doi: 10.1080/03093640600581099

Krause, M., de la Parra, G., Arístegui, R., Dagnino, P., Tomicic, A., Valdés, N., ..., \& Ramírez, I. (2007). The evolution of therapeutic change studied through generic change indicators. Psychotherapy Research, 17(6), 673689. doi: 10.1080/10503300601158814

Krause, M., de la Parra, G., Arístegui, R., Tomicic, A., Dagnino, P., Echavarri, O., ..., \& Altimir, C. (2006). Indicadores de cambio genéricos en la investigación psicoterapéutica [Generic indicators of change in the psychotherapeutic process]. Revista Latinoamericana de Psicología, 38(2), 299-325.

Landis, J., \& Koch, G. (1977). The measurement of observer agreement for categorical data. Biometrics, 33,159-174. doi: $10.2307 / 2529310$

Lambert, M., \& Burlingame, G. L. (1996). Outcome Questionnaire (OQ-45.2). Washington, DC: American Professional Credentialing Services.

Larraín, A., \& Medina, L. (2007). Análisis de la enunciación: 
Distinciones operativas para un análisis dialógico del discurso [Utterance analysis: Operative distinctions for a dialogical discourse analysis]. Estudios de Psicología, 28, 283-301. doi: 10.1174/021093907782506443

Leiman, M. (2004). Dialogical sequence analysis. In H. J. Hermans \& G. Dimaggio (Eds.), The dialogical self in psychotherapy (pp. 255-269). Hove, UK: BrunnerRoutledge.

Lincoln, Y., \& Guba, E. (1985). Naturalistic Inquiry. California: Sage.

Luborsky, L. (1994). Therapeutic alliances as predictors of psychotherapy outcomes: Factors explaining the predictive success. In A. O. Horvath \& L. S. Greenberg (Eds.), The working alliance: Theory, research, and practice (pp. 38-50). New York, NY: Wiley.

Marková, I. (2006). On "the inner alter" in dialogue. International Journal for Dialogical Science, 1(1), 125-147.

Martínez, C. (2011). Regulación mutua y dialogicidad en psicoterapia: Un análisis empírico de la subjetividad $e$ intersubjetividad en el discurso terapéutico [Mutual regulation and dialogue in psychotherapy: An empirical analysis of subjectivity and intersubjectivity in the therapeutic discourse]. Saarbrücken, Germany: EAE Publishing.

Martínez, C., Tomicic, A., \& Medina, L. (2012). Dialogic discourse analysis (DDA) of psychotherapeutic dialogue: Microanalysis of relevant psychotherapy episodes. International Journal for Dialogical Science, 6(1), 99-121.

Martínez, M., Tomicic, A., Pérez, C., Altimir, C., \& Krause, M. (2014). Manifestaciones verbales y no verbales de la regulación mutua en episodios relevantes de psicoterapia $y$ su relación con el proceso de cambio [Verbal and nonverbal expressions of mutual regulation in psychotherapeutic relevant episodes and their relation to the change process]. (Final report of project FONDECYT $\mathrm{N}^{\circ}$ 1110361). Santiago de Chile: Universidad Diego Portales. Retrieved from: http://www.milenio-depresion.cl/wp-content/uploads $/ 2013$

/10/InformeFinal_Regulaci\%C3\%B3n_2011_2013.pdf

Mitchell, S. A. (1988). Relational concepts in psychoanalysis. Cambridge, MA: Harvard University Press.

Ogden, T. (1994). Subjects of analysis. Northvale, NJ: Aronson.

Ogden, T. H. (2004). The analytic third: Implications for psychoanalytic theory and techniques. Psychoanalytic Quarterly, 73(1), 167-195.

Orange, D., Atwood, G., \& Stolorow, R. (1997). Working intersubjectively. Hillsdale, NJ: Analytic Press.

Orlinsky, D. E., Helge, M.., \& Willutzki, U. (2004). Fifty years of psychotherapy process-outcome research: Continuity and change. In M. Lambert (Ed.), Bergin and Garfield's handbook of psychotherapy and behavior change (pp. 307-389). New York: John Willey and Sons.

Ribeiro, E., Ribeiro, A., Goncalves, M., Horvath, A., \& Stiles, W. (2012). How collaboration in therapy becomes therapeutic: The therapeutic collaboration coding system. Psychology and Psychotherapy: Theory, Research, and Practice, 86(3), 294-314. doi: 10.1111/j.2044-8341.2012. 02066.x

Safran, J. D., \& Muran, J. C. (1996). The resolution of ruptures in the therapeutic alliance. Journal of Consulting and Clinical Psychology, 64, 447-458. doi: 10.1037 /0022006X.64.3.447

Safran, J. D., \& Muran, J. C. (2000). Negotiating the therapeutic alliance. New York, NY: Guilford Press.

Safran, J. D., \& Muran, J. C. (2006). Has the concept of the therapeutic alliance outlived its usefulness? Psychotherapy, Theory, Research, Practice, Training, 43(3), 286-291. doi: 10.1037/0033-3204.43.3.286

Safran, J. D., Muran, J. C., \& Samstag, L. W. (1994). Resolving therapeutic alliance ruptures: A task analytic investigation. In A. O. Horvath \& L. S. Greenberg (Eds.), The working alliance: Theory, research, and practice (pp. 225255). New York, NY: Wiley.

Sommerfeld, E., Orbach, I., Zim, S., \& Mikulincer, M. (2008). An in-session exploration of ruptures in working alliance and their associations with clients' core conflictual relationship themes, alliance-related discourse, and clients' post-session evaluations. Psychotherapy Research, 18(4), 1-12. doi: 10.1080/10503300701675873

Stephen, S., \& Elliot, R. (2011). Developing the adjudicated case study method. Pragmatic Case Studies in Psychotherapy, 7(1), 230-241.

Stern, D. (1985). The interpersonal world of the infant. New York, NY: Basic Books.

Stern, D., Sander, L., Nahum, J., Harrison, A., Lyons-Ruth, K., Morgan, A, . . . \& Tronick, E. (1998). Non-interpretive mechanisms in psychoanalytic therapy. The 'something more' than interpretation. The process of change study group. International Journal of Psychoanalysis, 79, 903-921.

Stolorow, R. (2002). Impasse, affectivity, and intersubjective systems. Psychoanalytic Review, 89(3), 329-327.

Stolorow, R., \& Atwood, G. (1992). Contexts of being: The intersubjective foundations of psychological life. Hillsdale, NJ: Analytic Press.

Timulak, L. (2007). Identifying core categories of clientidentified impact of helpful events in psychotherapy: A qualitative meta-analysis. Psychotherapy Research, 17(3), 305-314. doi: 10.1080/10503300600608116

Tomicic, A., \& Martínez, C. (2011). Voice and psychotherapy: Introduction to a line of research on mutual regulation in psychotherapeutic dialog. PRAXIS. Revista de Psicología, 13(20), 109-139.

Tomicic, A., Martínez, C., \& Krause, M. (2014). The sound of change: A study of the psychotherapeutic process embodied in vocal expression. Laura Rice ideas revisited. Psychotherapy Research, 25(2), 263-276. doi: 10.1080/10503307.2014.892647

Tomicic, A., Martínez, C., Pérez, J., Hollenstein, T., Angulo, S., Gerstmann, A., . . \& \& Krause, M. (2014). Discursivevocal regulatory strategies in the psychotherapeutic interaction: A study with state space grid (SSG). Manuscript in preparation.

Tronick, E. (1989). Emotions and emotional communications in infants. American Psychologist, 44(2), 112-119. doi: 10.1037/0003-066X.44.2.112

Tronick, E. (1998). Dyadically expanded states of consciousness and the process of therapeutic change. Infant Mental Health Journal, 19, 290-299.

Viklund, E., Holmqvist, R., \& Zetterqvist, K. (2009). Clientidentified important events in psychotherapy: Interactional structures and practice. Psychotherapy Research, 19, 1-14. doi: 10.1080/10503300903170939

Winnicott, D. (1965). The maturational process and the facilitating environment. New York, NY: International Universities Press.

Submitted August 15, 2013

Revision accepted February 14, 2014

Published March 1, 2015 
Appendix 1/3

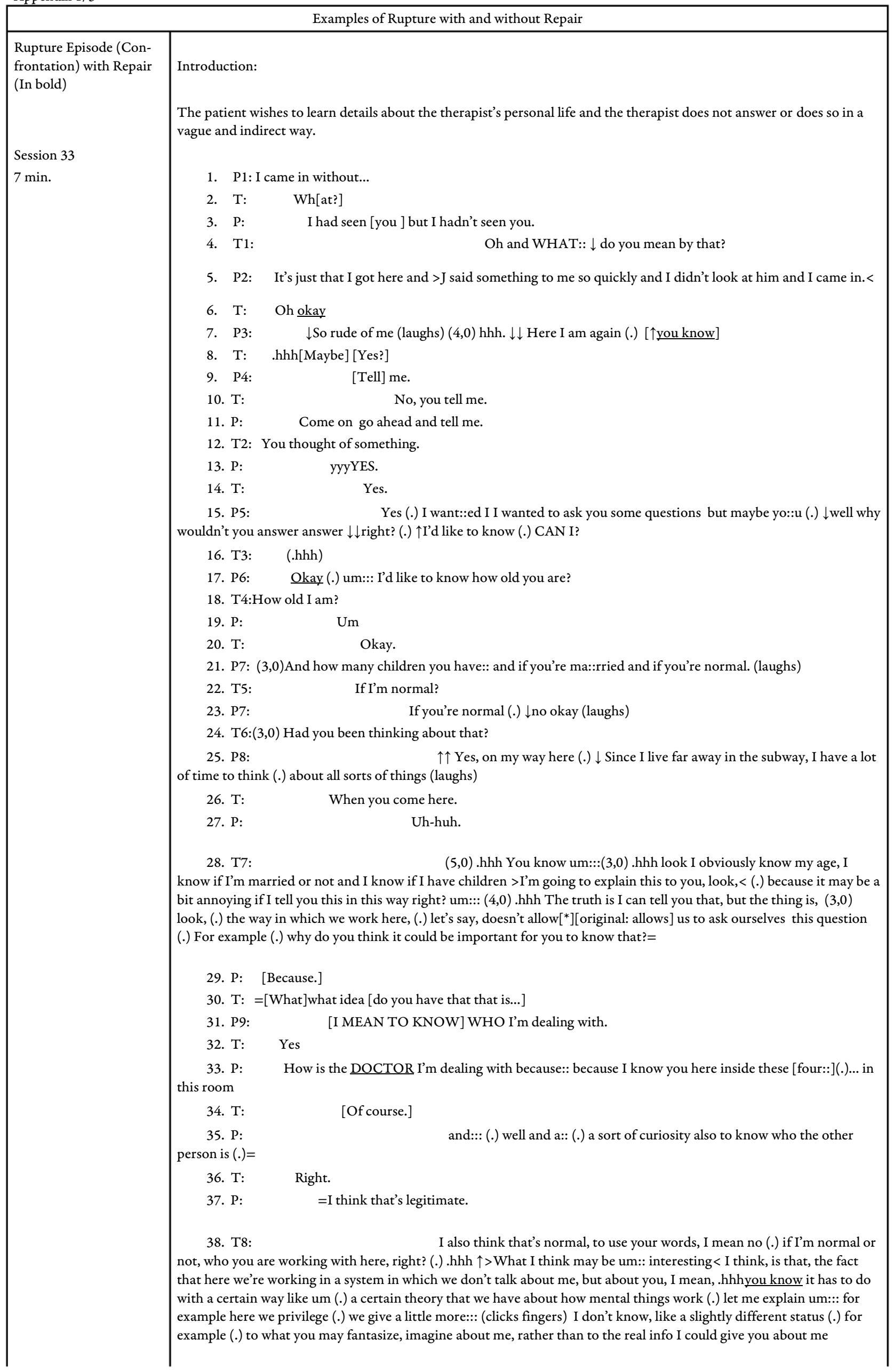


39. P10:

normal for you to answer.

40. T9: $\quad$ I agree I find it natural (.) What I'm show[ing] you

41. P11: [WHAT I]REALLY don't like:: the:: the tone in which you said I can tell you this or I can't tell you that $($.$) yes yes I know, [ but it is also] legitimate=$
42. $\mathrm{T}$ :
[Yes how?]
43. P:
$=$ HOW YOU EXPRESSED IT

44. T10:

$(3,0)$ How I expressed it now.

45. P:

Now?

46. T: Just now.

47. P:

Just now, uh-huh

48. T: .hhh okay I [would] like

49. P12: [SOUN]DED A BIT AGGRESSIVE LIKE: I can tell you yes yes (.) how old I am, when:: but I can also tell you nothing (.) Do you know what I mean?

50. T11:

to you (.) a little
51. P13:
NO SORT OF aggressive I mean (XXX) who I am and why $(3,0)$ I have
52. $\mathrm{T}:$ [oh:::]

Oh::: okay um(.) .hhh well maybe I said it in a way that could have sounded a bit ironic

53. P:

[I don't know] those are things (.) maybe they::: mostly to:: (.) start a topic or, or maybe I could tell you other things:: or have another picture of you or
54. $\mathrm{T}:$
[Yes.]

55. P:

[It must....]I don't know... I mean what (.) what you could tell me, I don't know (.) but it's not a question that, say, if it bothered you:: it has no other objective, it has no objective, but to know who the other person is just that (.) Uh-huh?

56. T12: .hh Look I think when I said to you that I can tell you my age and:: if I have children and if I'm married or not (.) .hhh actually look, I think that what I hhh. try to explain is that um:: $(3,0)$ it's a type of question which has to do with real life info (.) Right, I mean, obviously, I mean that um:: you have every right to wonder who I am, what I do, right, outside these four walls, right? (.) sSo what I'm saying is that I think the question is legitimate (.) What I'm explaining to you is that from the point of view of the working method (.) the working method (.) - it's not that I can't tell you where I live, what I do, maybe I could tell you things, other things too- (.) but, what I'm explaining to you is that the working method, that we have here um::: first attempts to look into what you can imagine about me (.) before the things you may know about me. Am I making myself clear? Right, because, look, that thing of being able to investigate, for example, what you imagine (.), anything you may think of, what you may:: associate, because it's inevitable, that for instance, how I look, like the other time when you noticed that maybe I was like in a rush, like in a hurry (.) Do you remember?

\section{P14: Yes.}

58. T13: In the session before last, when you thought maybe I was in a hurry, right? $(3,0)$ I think that considering the aim of our work, it's different for me to tell you why I may be in a hurry or what's been worrying me as a regular human being, for example, and to share that with you, or to give you that information, it's not the same as if we investigated what happens to you when you see me like that, what you can associate that with, or what kinds of images emerge in you or:: experiences

59. P15:

The truth is that no, I don't do it with any::, I don't associate it with

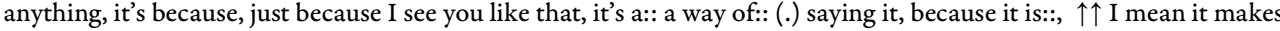
no:: sense maybe for:: for me to ask you if you're in a hurry because that's none of my business:: It's that..

60. T14: $\quad$.hhh EXCUSE ME, excuse me, I'll have to interrupt you.

61. P:

$\mathrm{Oh}$

62. T: you. For instance, if you see I'm in a rush, or looking worried::: it doesn't matter to you?

63. P16:

NO.

64. T15:

Please elaborate on that

65. P17: Just like it doesn't matter to me:: that YOU felt upset with my questions (.) I mean, in this case, no, no, it's not transcendental (.) it's not important either
66. T16:
$(3,0)$.hhh But this did bother you, [obviously]
67. P18:
[YES], the tone did bother me, it DID bother me.
68. T 17: Why? What did you feel? What, what do you think that::

69. P19:

Well I felt what:: I don't know. I mean, what many people may have felt, building building a big wall saying "don't interfere with my work" 


\begin{tabular}{|c|c|}
\hline & air \\
\hline $\begin{array}{l}\text { Rupture Episode (With- } \\
\text { drawal) without Repair }\end{array}$ & 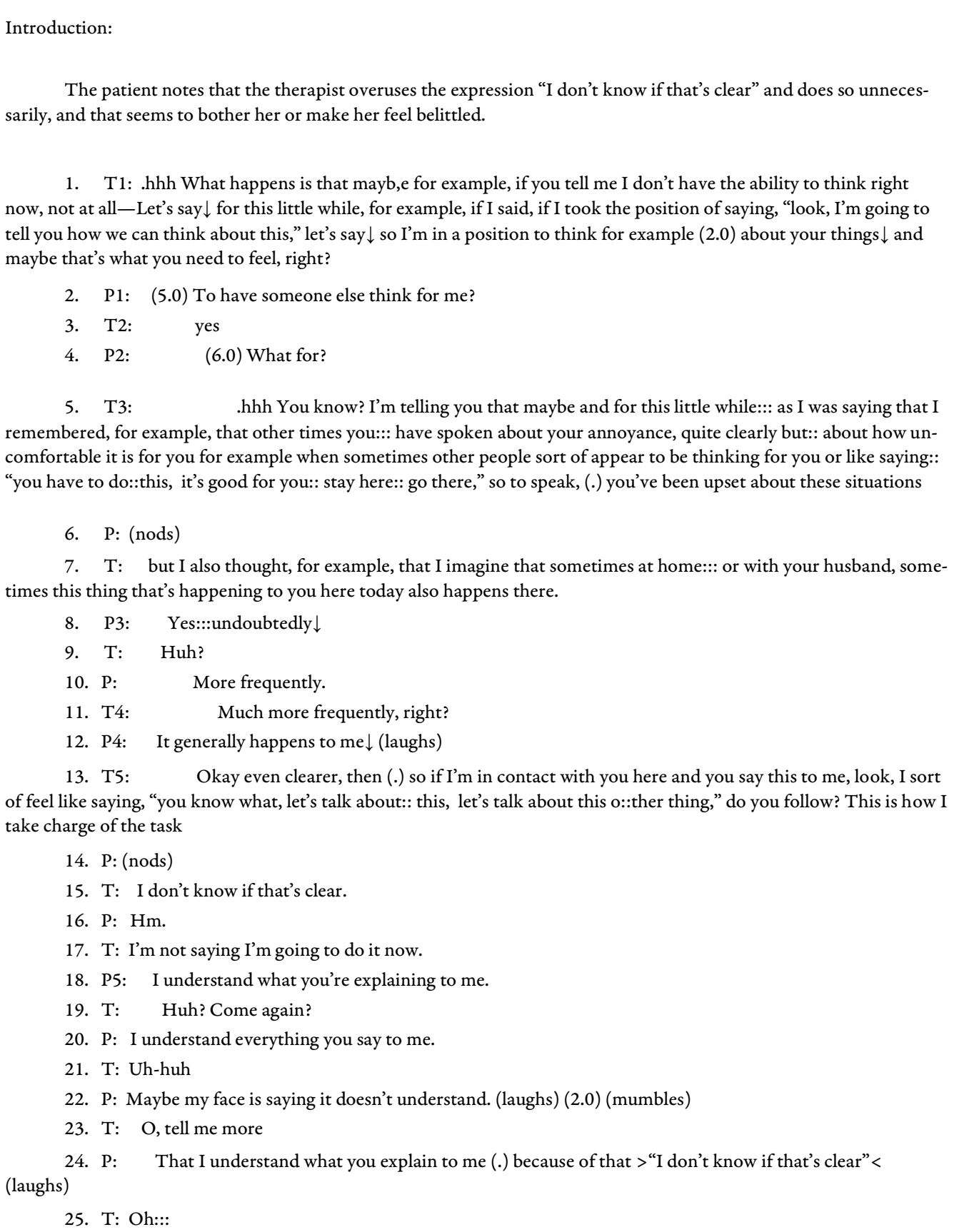 \\
\hline
\end{tabular}

